\title{
A Content Analysis of Health and Safety Communications Among Internet-Based Sex Work Advertisements: Important Information for Public Health
}

Julie Kille $^{1^{*}}$, RN, MSN; Vicky Bungay ${ }^{2^{*}}, \mathrm{RN}, \mathrm{PhD}$; John Oliffe ${ }^{3^{*}}, \mathrm{RN}, \mathrm{MEd}, \mathrm{PhD}$; Chris Atchison ${ }^{4}$, MA

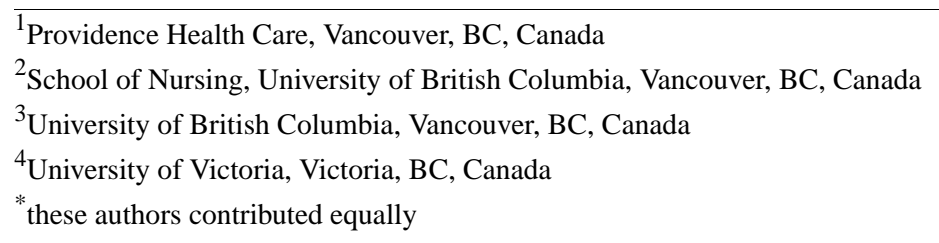

Corresponding Author:

Vicky Bungay, RN, PhD

School of Nursing

University of British Columbia

111-2176 Health Sciences Mall

Vancouver, BC, V6T1Z3

Canada

Phone: 116048227933

Fax: 16048227466

Email: vicky.bungay@ubc.ca

\section{Abstract}

Background: The capacity to advertise via the Internet continues to contribute to the shifting dynamics in adult commercial sex work. eHealth interventions have shown promise to promote Internet-based sex workers' health and safety internationally, yet minimal attention has been paid in Canada to developing such interventions. Understanding the information communicated in Internet-based sex work advertisements is a critical step in knowledge development to inform such interventions.

Objective: The purpose of this content analysis was to increase our understanding of the health and safety information within the Internet advertisements among women, men, and transgender sex workers and to describe how this information may be utilized to inform eHealth service development for this population.

Methods: A total of 75 Internet-based sex worker advertisements (45 women, 24 men, and 6 transgender persons) were purposefully selected from 226 advertisements collected as part of a larger study in Western Canada. Content analysis was employed to guide data extraction about demographic characteristics, sexual services provided, service restrictions, health practices and concerns, safety and security, and business practices. Frequencies for each variable were calculated and further classified by gender. Thematic analysis was then undertaken to situate the communications within the social and commercialized contexts of the sex industry.

Results: Four communications themes were identified: (1) demographic characteristics; (2) sexual services; (3) health; and (4) safety and security. White was the most common ethnicity $(46 / 75,61 \%)$ of advertisements. It was found that 20-29 years of age accounted for 32 of the 51 advertisements that provided age. Escort, the only legal business title, was the most common role title used $(48 / 75,64 \%)$. In total, $85 \%(64 / 75)$ of advertisements detailed lists of sexual services provided and $41 \%(31 / 75)$ of advertisements noted never offering uncovered services (ie, no condom). Gender and the type of Web-based platform mattered for information communicated. It was found that 35 of the 45 women's advertisements were situated in personal websites and hosted details about nonsexual aspects of an appointment. Men and transworkers used Internet classified advertisement platforms with predetermined categories. Communications about sexually transmitted infections (STIs) occurred in only 16\% (12/75) of advertisements with men accounting for 7 . Women's advertisements accounted for 26 of the 37 advertisements noting safety restrictions. Zero men or transpersons restricted alcohol or drug use. In total, $75 \%$ (56/75) of advertisements offered out-call services and the average minimal hourly rate ranged from Can $\$ 140 / \mathrm{h}$ to Can $\$ 200 / \mathrm{h}$. 
Conclusions: The study findings contribute to understandings about the diverse platforms used in commercial sex advertisements, and how sex workers frame information for potential clients. This information affords health care providers and policy makers insights to how they might assist with promoting the health of Internet-based sex workers and their clients.

(J Med Internet Res 2017;19(4):e111) doi: 10.2196/jmir.6746

\section{KEYWORDS}

eHealth; communication; confidentiality; cross sectional studies; gender; health behavior; Internet; sex industry; sexual health

\section{Introduction}

\section{Background}

The capacity to advertise via the Internet continues to contribute to the shifting dynamics in adult commercial sex work $[1,2]$ creating unprecedented opportunities for sex workers to determine how they will conduct business and allowing for greater control over their work [3]. Health-related benefits associated with Internet-based sex work, defined as the use of Internet by adults to facilitate consensual exchange of sexual services for money, include increased income, autonomy, and safety when compared with street-level sex work or working for a third party [1,4-6]. Internet-based sex workers can also, however, experience depression, isolation, violence, sexually transmitted infections (STIs), and substantial barriers in accessing and receiving health services [2,7-13].

Internationally, eHealth interventions have shown promise to promote health and safety among Internet-based sex workers $[14,15]$. Minimal attention has been paid in Canada, however, to developing interventions tailored to this population. The dearth of information about Internet-based sex work and the health practices and experiences of those involved may be contributing to oversights in eHealth intervention development $[8,9,16]$.

Currently, the Internet is the primary advertisement medium used within the commercial sex industry. Internet advertisements for independent (ie, self-employed) Internet-based sex workers are in the hundreds of thousands each day on an international scale [1,17-23]. The analysis of information communicated within Internet-based sex work advertisements offers great promise to help improve our understanding of this population and the health and safety norms and expectations within the sex industry $[8,10,21]$. Indeed, an analysis of Internet advertisement content is a critical step in contributing to the knowledge needed to develop targeted and effective eHealth interventions.

To date, a small number of international studies have contributed to an evolving knowledge base about the content of Internet sex work advertisements. Although variation in the level of detail in advertisements occurs, preliminary evidence indicates that information about sexual services, pricing, locations, physical and interpersonal characteristics, and contact instructions are commonly included [8,13,19,21-28]. Gender variations in content have been reported suggesting that descriptions of personal spaces, personalities, and noncommercial services such as dinner and companionship are more common to women's advertisements [19]. By contrast, personal biographical statements and information about who they provide services to (eg, men, women, and couples) appear more consistently in men's advertisements [22]. Photographs are frequently included although many are partial images where the person's face is not fully recognizable; a situation that may reflect concerns about confidentiality and privacy [19,27].

Much of the extant research on the content of Internet advertisements emphasizes men selling sexual services to other men with some conflicting results about their health practices $[12,25,26]$. In one US study, for instance, it was reported that $19 \%$ of Internet advertisements by men cited exclusive safer sex practices [24]. Conversely $90 \%$ of advertisements in a separate US project cited always engaging in safe sex and $16 \%$ included a statement of a preference for drug use during sexual activities [8]. Research concerning women Internet-based sex work advertisements and health and safety is minimal. Women's advertisements are frequently investigated from male clients' perspectives emphasizing clients' discussions and reviews of sex workers embedded in Internet social networking forums [28] or analysis framed by queries about what male clients find attractive [27]. Moreover, research concerned with the content of Internet advertisements has focused on marketing strategies, sexual service information, and privacy concerns about sex workers' identities. Less attention has been paid to the types of health, safety, and transactional information that are communicated within these advertisements.

\section{Purpose of the Study}

In this paper, we contribute to the growing knowledge about Internet-based sex work by detailing the results of a content analysis of Web-based advertisements within a Canadian context. The study purpose was to increase understandings of the health and safety information within Internet-based sex work advertisements and to offer suggestions for how this information may be utilized to inform eHealth program development. Because people of all genders engage in sex work [29] and gender matters for health [30], the content of Internet advertisements were examined within and between subgroups of women, men, and transgender or transpersons (defined as individuals who were assigned a sex at birth but express and experience their gender differently; however, they do not necessarily undergo sex reassignment or corrective surgery) [16] engaged in sex work.

\section{Methods}

\section{Overview}

This study was conducted using a content analysis approach $[31,32]$ following university ethics approval. Content analysis has been used extensively by gender scholars to compare the information noted in Internet- and media-based communications of men and women [33]. Included were a series of iterative and 
systematic processes that involved creating an empirically derived sample of Internet advertisements, determining the unit of analysis (eg, words, phrases, photos), developing a categorical scheme to code the data, and conducting data analysis [32].

\section{Sample}

The sample consisted of 75 verified Internet advertisements for sexual services provided by women $(n=45)$, men $(n=24)$, and transgender people $(n=6)$ advertising specifically in Vancouver, British Columbia, Canada. The empirically driven sample [32] was selected from a database of 226 Web-based Canadian advertisements of women ( $n=173)$, men (35), and transgender $(n=20)$ workers collected during ethnographic mapping activities of a larger study examining the relationships between health, safety, and the organizational features of an indoor sex industry. Ethnographic mapping involved a series of key informant interviews to detail prominent classified websites and search strategies for personal business websites situated within the local context, visiting the websites and classifieds 2 times per week over a 4-week period to collate number of posts and strategize for duplication removal, and narrowing to 3 Web-based classified platforms that were used most consistently; the details of which are described elsewhere [20]. Purposeful sampling was used to capture the diversity in Web-based sex advertisement formats including advertisements from 35 personal websites and 40 from 3 Web-based classified advertising platforms. All advertisements were publicly accessible and membership or sign-in was not a requirement.

\section{Data Collection}

Due to the potential temporary nature of Internet advertisements, screenshots were taken and downloaded to a password-protected folder (see Multimedia Appendix 1). Drawing from previous research on the content of information communicated within Internet-based sex work advertisements [8,12,19,21,22,25-27,34] and the study objectives, a coding scheme that included relevant, advertisement-specific variables and related operational definitions (Table 1) was used [21,33]. Each variable was also coded as a categorical "yes" or "no" to document variable presence or absence within the advertisement. Data extraction and coding were undertaken by the first two authors collaboratively to aid reliability of the coding process. Data extraction of the variables and associated measures was completed by using a Microsoft Excel file template.

Table 1. Variables and operational definitions.

\begin{tabular}{|c|c|}
\hline Variable & Operational definition \\
\hline Sexual services provided & $\begin{array}{l}\text { Sexual service provision communications }{ }^{\mathrm{a}} \text { refer to the types of sexual acts that the person offers within their } \\
\text { advertisement. }\end{array}$ \\
\hline Sexual service restrictions & $\begin{array}{l}\text { Restriction communications refer to the sexual services that the person advertising reports being unwilling to } \\
\text { engage in during the provision of sexual services. }\end{array}$ \\
\hline \multirow[t]{2}{*}{ Health } & $\begin{array}{l}\text { Health communications were operationalized into two categories: (1) communications that specifically speak } \\
\text { to health-related practices that could be considered protective or nonprotective for health (eg, nonsmoker, drug }\end{array}$ \\
\hline & use, condom use) and (2) presence or absence of specific health issues (eg, HIV ${ }^{\mathrm{b}}$, sexually transmitted infections). \\
\hline Safety and security & $\begin{array}{l}\text { Safety and security communications refer to factors associated with positively or negatively affecting people's } \\
\text { physical, emotional, and financial well-being including their privacy. Specific categories for extraction included } \\
\text { (1) location where sexual services provided, (2) instructions for clients on how to prepare for the encounter, (3) } \\
\text { security measures taken before encounter including screening processes, (4) security measures during the en- } \\
\text { counter, and (5) facial photo details. }\end{array}$ \\
\hline Business practices & $\begin{array}{l}\text { Business practices refer to communications that detail the dollar amounts associated with the cost of sexual } \\
\text { services, contact and booking processes, and related restrictions. }\end{array}$ \\
\hline
\end{tabular}

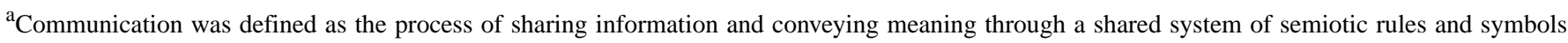
[35]. Hypertexts or the array of words, phrases, and images found within advertisements were the focus of data collection [32].

${ }^{\mathrm{b}}$ HIV: human immunodeficiency virus.

\section{Data Analysis}

Variable frequencies were calculated using descriptive statistics and further classified according to gender. The social and commercialized contexts in which the information was embedded were also considered [32], including norms of language, the legal status of sex work in Canada, and the diversity of sexual services and Web-based advertising formats within the marketplace [9]. Thematic analysis of the hypertexts and related frequencies were undertaken to synthesize and categorize types of information communicated and the gender similarities and differences within the social and commercial contexts of the Web-based advertisements. Four communication themes were identified: demographics, sexual services, health, and safety and security.

\section{Results}

\section{Overview}

The 75 advertisements varied in structure and format in how the information was communicated and organized. All the 75 advertisements marketed sex services to men and 2 men's advertisements additionally advertised services for women clients. In total, 78\% (35/45) of women's advertisements were 
within their personal business websites, whereas men's (22/24; $83 \%)$ and transpersons' advertisements $(5 / 6 ; 83 \%)$ appeared within Internet classified advertising platforms. Unlike tailored personal websites, the advertisements within the classified platforms adhered to an advertising template with information organized into predetermined categories (eg, age, weight, services offered, classification). Women's advertisements within their personal websites frequently described their workspaces in detail with emphasis on the provision of a relaxing atmosphere. Classified platforms did not afford the opportunity to detail a space, only whether or not one was provided. Health, safety, demographic characteristics, and sexual services were regularly communicated in the 75 advertisements regardless of platform used.

\section{Demographic Communications}

Sex industry language norms were evident in the work titles and physical characteristics communicated throughout the advertisements with variations that mapped onto gender. Although "escort" was the most common work title (Table 2) across groups, it was the only term used in the men's and transpersons' advertisements. By contrast, almost half of the women's advertisements included other titles that evoked specific heterosexual erotic identities, such as "courtesan," "playmate," or "dominatrix." The use of escort for a work classification may also be understood within the constraints of the Canadian laws that criminalize communications associated with selling and purchasing sexual services. The term "escort," for example, is a legally recognized business title within the City of Vancouver municipal bylaws [36], whereas other titles are not. Additionally, the laws may contribute to restrictions on some of the Web-based classified platforms regarding language permitted within their site.

Table 2. Demographic characteristic communications.

\begin{tabular}{|c|c|c|c|c|}
\hline Characteristics & $\begin{array}{l}\text { Women } \\
(\mathrm{n}=45)\end{array}$ & $\begin{array}{l}\text { Men } \\
(\mathrm{n}=24)\end{array}$ & $\begin{array}{l}\text { Transgender persons } \\
(\mathrm{n}=6)\end{array}$ & $\begin{array}{l}\text { Total } \mathrm{n}=75 \\
\mathrm{n}(\%)\end{array}$ \\
\hline \multicolumn{5}{|l|}{ Work title } \\
\hline Escort & 18 & 24 & 6 & $48(64)$ \\
\hline Companion & 5 & & & $5(7)$ \\
\hline Multiple roles & 4 & & & $4(5)$ \\
\hline Other & 10 & & & $10(13)$ \\
\hline Not specified & 8 & & & $8(10)$ \\
\hline \multicolumn{5}{|l|}{ Age (years) } \\
\hline $20-29$ & 14 & 16 & 2 & $32(43)$ \\
\hline $30-39$ & 9 & 4 & 1 & $14(18)$ \\
\hline $40-49$ & 1 & 3 & 1 & $5(7)$ \\
\hline Not specified & 21 & 1 & 2 & $24(32)$ \\
\hline \multicolumn{5}{|l|}{ Ethnicity } \\
\hline White & 29 & 13 & 4 & $46(61)$ \\
\hline Black & 2 & 1 & & $3(4)$ \\
\hline Latino or Hispanic & 1 & 3 & & $4(5)$ \\
\hline Asian & 9 & 4 & 1 & $14(19)$ \\
\hline Multiethnic & 4 & 3 & 1 & $8(10)$ \\
\hline \multicolumn{5}{|l|}{ Weight } \\
\hline Advertisements specifying weight & 25 & 24 & 4 & $53(71)$ \\
\hline Average of specified weights (lbs) & 118 & 167 & 135 & \\
\hline
\end{tabular}

In total, 25 of the 75 advertisements did not specify the sex workers' ethnicity. In these cases, photos accompanying advertisements provided an indication from which ethnicity was estimated. White was the most common ethnicity stated or observed (Table 2). Men's advertisements were the only ones to consistently provide age, weight, and ethnicity (Table 2), which may reflect the template of the classifieds' advertising platforms. Two transpersons' advertisements communicated surgical or hormone replacement therapy details such as "undergone hormone replacement therapy" or "nonoperative transsexual" highlighting the significance of language to communicate about their embodied specificities. Men's communications detailed their muscular build or fitness, for instance, "physically fit, muscular" or "lean or swimmer build" and included physical characteristics, the most common being weight, body hair, body type, and penis size. This differed from the women and transpersons' advertisements wherein physical 
descriptions such as bust size were present in some cases but did not appear uniformly.

\section{Sexual Service Communications}

The language used to communicate about sexual services among the 64 advertisements listing sexual services reflected sex industry norms. Variation between genders and homogeneity within was observed (Table 3). The term "full service," communicating to clients a willingness to engage in sexual activities that included vaginal intercourse was found within women's advertisements. Women also listed the "girlfriend experience (GFE) or boyfriend experience (BFE)," which is defined as the provision of dating activities and sex that would be expected in a noncommercial adult relationship [37], more often than men. Men's and transgender peoples' advertisements used the terms "top," "bottom," or "versatile," indicating their sexual positions for anal intercourse. Men also used the term "anal" explicitly, whereas women used the term "greek" to indicate anal services.

Table 3. Sexual services communications.

\begin{tabular}{|c|c|c|c|c|}
\hline Characteristics & $\begin{array}{l}\text { Women } \\
(n=45)\end{array}$ & $\begin{array}{l}\text { Men } \\
(\mathrm{n}=24)\end{array}$ & $\begin{array}{l}\text { Transgender persons } \\
(\mathrm{n}=6)\end{array}$ & $\begin{array}{l}\text { Total } \mathrm{n}=75 \\
\mathrm{n}(\%)\end{array}$ \\
\hline Advertisements with services listed & 35 & 23 & 6 & $64(85)$ \\
\hline \multicolumn{5}{|l|}{ Type of services } \\
\hline Full service & 20 & & & $20(27)$ \\
\hline Massage & 18 & 18 & & $36(48)$ \\
\hline $\mathrm{GFE}^{\mathrm{a}}$ or $\mathrm{BFE}^{\mathrm{b}}$ & 17 & 2 & 1 & $20(27)$ \\
\hline Companionship & 12 & 12 & & $24(32)$ \\
\hline Duos & 12 & 1 & & $13(17)$ \\
\hline BDSM & 12 & 12 & 1 & $25(33)$ \\
\hline Greek or anal & 6 & 16 & 3 & $25(33)$ \\
\hline Uncovered services & 11 & 6 & 1 & $18(24)$ \\
\hline Top (position) & & 6 & & \\
\hline Bottom (position) & & 6 & & \\
\hline Versatile (top or bottom) & & 11 & 2 & \\
\hline Advertisements with service restrictions & 26 & 9 & 2 & $37(49)$ \\
\hline
\end{tabular}

${ }^{\mathrm{a}} \mathrm{GFE}$ : girlfriend experience.

${ }^{b}$ BFE: boyfriend experience.

The language of men's advertisements was further associated with terms that are used to describe specific sexual practices between men, for instance, "rimming, fisting, and watersports," and included detailed lists of sexual acts that they would engage in. Diverse BDSM services were listed across genders. BDSM is a term used to denote varied consensual sexual practices that include bondage, domination or submission, pain or sensation play, power exchange, leathersex, role playing, and fetishes [38]. The women's advertisements offering BDSM services additionally communicated information about health and safety. Clients were asked to provide information about any medical issues and a safe word to signal when they wanted to stop the activity before services. Women's advertisements more often identified and provided hyperlinks to the websites of other men and women sex workers with whom they worked as part of their "duo" services (Table 3).

Communications about condom use included the terms "covered" (ie, condom) and "uncovered" (ie, no condom required) with service variations noted among the 64 advertisements listing services. Uncovered services were usually specific to oral-genital sex (Table 3). Women used industry acronyms such as BBBJ (bareback blowjob), CIM (cum in

mouth), DATY (dining at the Y/cunnilingus), and DATO (dining at the O/analingus) to detail the service. Uncovered analingus or "rimming," was offered in 6 of the 23 men's advertisements listing services. In contrast, $41 \%$ (31/75) of advertisements stated that they never provided uncovered services, often describing their services as "always safe" (see Multimedia Appendix 2). Women communicated more restrictions overall, sometimes posting an "etiquette" or "frequently asked questions" section that outlined restrictions.

\section{Health Communications}

There were noteworthy gender-based variations in the Web-based information about personal health practices. Transworkers' advertisements rarely communicated any personal health information, whereas men and women consistently provided health-related details. Communications about cigarette smoking and substance use were the most common types of personal health practice communications (Table 4). It was found that $7 \%(3 / 45)$ of women's advertisements also contained communications requesting clients refrain from smoking before or during appointments, and one of the women's advertisements indicated that she would not visit smoking rooms in hotels. 
Although none of the men or transgender persons explicitly restricted clients' drug or alcohol use, $22 \%$ (10/45) of women's advertisements stated a refusal to see a client who was, or appeared to be, under the influence of drugs or alcohol. It was found that $25 \%(6 / 24)$ of men's advertisements stating that they did use drugs noted being okay with "party and play" (PNP), a euphemism for acknowledgment of the availability for drugs, frequently crystal methamphetamine, to be taken in conjunction with having sex [39]. None of the advertisements stated specific illicit drugs with the exception of a 2 women's advertisements that specified being " 420 friendly" indicating marijuana was acceptable.
Communications about STIs were infrequent $(12 / 75,16 \%)$ and higher among men's advertisements. "Clean" and "infection-free" were the terms used. One of the men's advertisements communicated that he was "HIV-positive" but "undetectable," a status referring to HIV viral load as measured through serum testing [40]. His advertisement further noted that although bareback was preferred, he would provide covered services. Client hygiene was commented upon in women's advertisements only. Expectations of "good hygiene" were noted and they also included information about the facility to shower at their in-call before services (see Multimedia Appendix 2).

Table 4. Health communications.

\begin{tabular}{|c|c|c|c|c|}
\hline Characteristics & $\begin{array}{l}\text { Women } \\
(n=45)\end{array}$ & $\begin{array}{l}\text { Men } \\
(n=24)\end{array}$ & $\begin{array}{l}\text { Transgender persons } \\
(\mathrm{n}=6)\end{array}$ & $\begin{array}{l}\text { Total } \mathrm{n}=75 \\
\mathrm{n}(\%)\end{array}$ \\
\hline Health communications & 29 & 24 & 1 & $64(85)$ \\
\hline \multicolumn{5}{|c|}{ Sex workers' personal health behaviors communications } \\
\hline Nonsmoker & 16 & 9 & & $25(33)$ \\
\hline Nondrug using & 13 & 3 & & $16(21)$ \\
\hline "Social" alcohol use & 7 & 4 & & $11(15)$ \\
\hline Uses drugs & 2 & 6 & & $8(11)$ \\
\hline Other (physical activities such as yoga, gym) & 3 & 10 & 1 & $14(19)$ \\
\hline Communicable infection communications & 5 & 8 & & $12(16)$ \\
\hline
\end{tabular}

\section{Safety and Security Communications}

Communications associated with personal and financial safety and security occurred in all advertisements and were regularly embedded in information for potential clients to learn about the operational features of connecting with and making an appointment with a worker (Table 5). For example, in addition to detailing the location where appointments would be held, specific contact instructions were provided. Multiple options for making contact were consistently available across genders (Table 5); however, the patterns of use varied with men and transpersons' advertisements more frequently using the messaging features of the hosting classified advertisement platform. Women utilized a live (ie, phone) booking process with potential clients. It was found that $9 \%$ (7/75) advertisements noted not accepting blocked numbers for phone calls, of which 5 were in women's advertisements.

The advertisements also illustrated that Internet-based sex work occurs within in-call spaces such as apartments provided by the sex worker, and out-call locations where a sex worker travels to the client. Although there were limited restrictions communicated concerning out-call locations, gender variance was observed with only women communicating that they would not provide out-call services to private residences, or in hotels rated below a 4-5 star accommodation. It was found that $9 \%$ (4/45) of the women required references from another service provider and one woman required clients to check-in with hotel security before the exchange. None of the transworkers shared any communications about willingness to travel; although just under one-third and one-quarter of men and women's advertisements, respectively, noted this as an option.

Attempts to maintain privacy and security were also reflected in the photos provided within the advertisements. One-third of advertisements contained identifiable facial photos, including all of transpersons' advertisements, and one-half provided a viewable photo of some kind (Table 5). The partial face photos revealed features such as eyes or lips, or in some cases a side profile with shadowing that made it more difficult to identify the person in the photo. In total, 2 of the 45 women's advertisements explicitly noted that clients were not to take photos or videos during an appointment and one woman's advertisement stated that she would agree to photos and videos only if she was confident that they would never be posted on the Internet, but she did not state how that would be negotiated.

The communications about pricing provided concise information about fees. The price of service varied with women charging on average approximately $25 \%$ less than men per exchange (Table 5). Admittedly, the highest rate in the sample, Can $\$ 700 / \mathrm{h}$, was listed on a woman's site; however, the advertisement was an outlier in terms of fee. The men and transworkers' sites listed consistent prices per hour; and both men and women charged significantly more for travel and did not include the price of airfare, hotels, and meals, which was specified separately. 
Table 5. Safety and security communications.

\begin{tabular}{|c|c|c|c|c|}
\hline Characteristics & $\begin{array}{l}\text { Women } \\
(\mathrm{n}=45)\end{array}$ & $\begin{array}{l}\text { Men } \\
(\mathrm{n}=24)\end{array}$ & $\begin{array}{l}\text { Transgender persons } \\
(\mathrm{n}=6)\end{array}$ & $\begin{array}{l}\text { Total } \mathrm{n}=75 \\
\mathrm{n}(\%)\end{array}$ \\
\hline Safety and security restrictions for client behaviors identified & 26 & 9 & 2 & $37(49)$ \\
\hline \multicolumn{5}{|l|}{ Service locations } \\
\hline In-call & 35 & 12 & 3 & $50(67)$ \\
\hline Out-call & 34 & 18 & 4 & $56(75)$ \\
\hline Willing to travel out of town & 9 & 7 & & $16(21)$ \\
\hline Viewable facial photo & 22 & 11 & 5 & $38(51)$ \\
\hline Full & 13 & 9 & 5 & $27(36)$ \\
\hline Partial & 9 & 2 & & $11(15)$ \\
\hline \multicolumn{5}{|l|}{ Booking contact process } \\
\hline Phone & 35 & 15 & 5 & $55(73)$ \\
\hline Website & 15 & 19 & 3 & $37(49)$ \\
\hline Text & 8 & 1 & 1 & $10(13)$ \\
\hline Email & 18 & 5 & 9 & $32(43)$ \\
\hline \multicolumn{5}{|l|}{ Rates (Canadian dollar) } \\
\hline Minimum & 140 & 180 & 200 & \\
\hline Maximum & 700 & 450 & 250 & \\
\hline Average & 313 & 247 & 233 & \\
\hline
\end{tabular}

\section{Discussion}

\section{Principal Findings}

The study findings build on nascent empirical understandings of the content of Web-based advertisements [19,22,23,27,41]. This research also contributes particular topics for consideration in public health and eHealth programming among the growing population of sex workers who use the Internet as their primary means to communicate, at least initially, occupational health and safety details to potential clients. In these advertisements, sex workers communicated significant information that reflected their personal health practices both within and outside commercial sex exchanges (eg, drug and alcohol use, condom use, physical fitness). These health communications provide important insights to the nature and norms of Internet-based sex work and the practices, health behaviors, and overall wellbeing of those advertising in this context.

The findings also illustrate that gender matters when considering health and safety practices and Internet-based communications. Women list more safety communications overall and do so by communicating restrictions, particularly about place and substance use. Women also use personalized screening processes involving live phone communications to determine the suitability of the client [5]. Men and transpersons communicate minimal safety details. These finding adds nuance to our understandings about different strategies between men and women sex workers to mitigate risks of violence $[13,42,43]$ by demonstrating the role of Internet-based communications within the realm of the commercialized exchange. Gender and technology also intersect to influence the content of communications including how information is presented, language used, and the actual types of details included. Women tend to use personal business websites to advertise providing substantial details about etiquette and atmosphere. Men and transpersons use Web-based classified platforms with predetermined categories and emphasize physical characteristics. Understanding the gender nuance of advertising platforms is essential to developing targeted eHealth messaging that takes into consideration the norms of communication within the realm of the diverse platforms used $[1,18]$.

The findings also provide some new insights into population characteristics within Canadian advertisements situated in this locale as predominantly white, young workers who charged over Can $\$ 200 / \mathrm{h}$, on average, for their services in both in-call and out-call settings. These characteristics are similar to those described in other North American Internet-based sex work research $[27,44]$ and in direct contrast to research situated in street-based marketplaces that demonstrate higher numbers of Indigenous, Black, and Hispanic people aged over 30 years and diverse financial arrangements where fees charged are amount per service with much lower income potential $[25,45]$. As expected, the snapshot of the Internet-based sex industry captured in these 75 advertisements also indicates that men, women, and trans-sex workers provide services almost exclusively to male clients.

The health communications regarding condom use raised several important issues warranting attention. Condom use was regularly communicated for anal or vaginal intercourse, yet less than half of the advertisements communicated that a condom was required for oral-genital sex. Although there is growing evidence that many sex workers may experience STI infection rates similar to or less than the general population $[12,46,47]$, the lack of condom requirement for oral-genital sex may still pose a 
significant health threat for them $[41,48,49]$. For example, STIs such as syphilis, gonorrhea, and chlamydia can be transmitted via oral-genital contact and can be asymptomatic [50]. Women aged under 30 years and men having sex with men are disproportionately affected by some STIs [51]; an important fact given the demographic characteristics of the study sample. Moreover, there is some evidence that sex workers, like many in the general population, may not fully comprehend the possibilities of transmission of STIs through oral-genital body fluid exchange [52,53].

Developing health promotion strategies for condom use, however, requires nuanced understandings of evolving commercial sex industry norms. Men and women Internet-based sex workers are engaged in offering emotionally erotic exchanges for sale and purchase that are designed to foster intimacy and replicate aspects of noncommercial relationships [54,55]. Additionally, the demand for unprotected sexual services is steadily on the rise and is directly contributing shifting norms and economic influences shaping safer sex practices $[47,53]$. It has been demonstrated, for instance, that women's willingness to engage in uncovered oral sex is associated with increased earnings offered by clients for those services irrespective of their health-related knowledge [53]. How the issues of knowledge, intimacy, companionship, economy, and shifting norms influence people's practices, their health and safety highlights the need for contextually appropriate approaches to sexual health promotion and STI prevention. Contextually appropriate approaches that take into consideration the multiple cofactors that can contribute to STI transmission and the diverse needs that people may have with regards to building prevention capacity have been shown effective in diverse populations [56]. It is, therefore, critical that public health consider how to target multiple interrelated issues such as money, intimacy, and familiarity in the campaigns aimed at promoting sexual health and people's safer sex behaviors.

Finally, Internet-based sex workers are often considered a hard-to-reach group particularly because their businesses operate in limitless Web-based spaces afforded by Internet-based advertising services [20]. Isolation and barriers in access to health promotions services have been noted among this population [7-13]. eHealth programs delivered via the Internet are often successful because of their potential to reach people who experience isolation [57]. To be effective, however, it is essential that such health programming be developed to reach the diversity of sex workers and to do so, programming must involve the active participation of those engaged in sex work in the design and implementation [11,58,59]. As the World Health Organization (WHO) strategy for the health promotion of sex workers noted, "health services should be made available, accessible, and acceptable to sex workers" (p.xix). Moreover, health promotion programs that build upon the existing strengths and the knowledge base of sex workers have a proven track record as the most successful to promote health and safety [11]. Additionally, health promotion strategies must include and extend beyond STI prevention. The need for greater knowledge and skills in the areas of safe and effective Internet advertising strategies, attracting and screening appropriate clients, addressing legal concerns, and financial planning — an important aspect of transitioning out of the industry have been identified $[44,60]$. Given the evidence of increased autonomy and independence associated with Internet-based sex work [4-6], there is perhaps an opportunity for health programming to capitalize on the benefits of autonomy and control in sex workers' choice to communicate explicit Web-based restrictions, and to promote and expand self-health in the sex industry as a highly desirable and marketable characteristic.

\section{Limitations}

The research is limited by the small sample and the limited information gleaned from the transworkers' advertisements. And, although content analysis provides some information to help understand health and safety practices, additional research with a larger sample that includes the perspectives and experiences of Internet-based sex workers is warranted.

\section{Conclusions}

This descriptive study is one of the first to analyze the content of Internet-based sex work advertisements in Canada, and is one of a few to include men, women, and transgender people in a single study. Content analysis is a feasible approach to understanding Internet-based communications and must be nuanced within the social and commercialized context of the sex industry to help inform health service programming for Internet-based sex workers [44]. Strategies for eHealth promotion must be informed by more relational approaches to sex and intimacy that are inclusive of sex workers and their clients and considers gender-specific aspects of these relationships. As the Internet continues to grow, greater numbers of sex workers will likely advertise services via the Internet. Important insights can be gleaned by describing Internet advertisement content about industry practices including the emergence of self-management akin to small business ownership. With this in mind, we might thoughtfully continue to describe Internet-based sex workers' advertisements as a means to developing more effective eHealth programming to better support the health of sex workers and their clients.

\section{Acknowledgments}

This paper is based on the research of Julie Ann Kille for her Master of Science degree in Nursing, 2015, at the University of British Columbia, Vancouver, Canada and the SPACES (sex, power, agency, consent, environment, safety) study. Funding for this project was provided by the Canadian Institutes for Health Research (grant number MOP-11947). Vicky Bungay is partially supported by a Canada Research Chair in Gender, Equity and Community Engagement and Michael Smith Foundation for Health Scholar Award (grant number 5212). 


\section{Conflicts of Interest}

None declared.

\section{Multimedia Appendix 1}

Sample screenshots from a personal business website and a Web-based classified advertising site.

[PDF File (Adobe PDF File), 225KB-Multimedia Appendix 1]

\section{Multimedia Appendix 2}

Additional advertising details are provided in table format concerning communications about restrictions, infections, and rules for client health behaviors.

[PDF File (Adobe PDF File), 38KB-Multimedia Appendix 2]

\section{References}

1. Ashford C. Male sex work and the Internet effect: time to re-evaluate the criminal law? J Crim Law 2009 Jun;73(3):258-280. [doi: $10.1350 /$ jcla.2009.73.3.573]

2. Murphy AK, Venkatesh SA. Vice careers: the changing contours of sex work in New York City. Qual Sociol 2006 Jun 27;29(2):129-154. [doi: 10.1007/s11133-006-9012-2]

3. Pitcher J. Sex work and modes of self-employment in the informal economy: diverse business practices and constraints to effective working. Soc Policy Soc 2015 Jan;14(1):113-123 [FREE Full text] [doi: 10.1017/S1474746414000426] [Medline: 25506264]

4. Argento E, Taylor M, Jollimore J, Taylor C, Jennex J, Krusi A, et al. The loss of Boystown and transition to online sex work: strategies and barriers to increase safety among men sex workers and clients of men. Am J Mens Health 2016 Jun 28:1-12 Epub ahead of print. [doi: 10.1177/1557988316655785] [Medline: 27352925]

5. Atchison C, Benoit C, Burnett P, Jansson M. NSWP. 2015. The influence of time to negotiate on control in sex worker-client interactions URL: http://www.nswp.org/sites/nswp.org/files/R4SW\%202015 issue14 PDFV.pdf [accessed 2016-10-04] [WebCite Cache ID 612cU7yIN]

6. Minichiello V, Scott J, Callander D. New pleasures and old dangers: reinventing male sex work. J Sex Res 2013;50(3-4):263-275. [doi: 10.1080/00224499.2012.760189] [Medline: 23480072]

7. Bar-Johnson MD, Weiss P. A comparison of male sex workers in Prague: Internet escorts versus men who work in specialized bars and clubs. J Sex Res 2015;52(3):338-346. [doi: 10.1080/00224499.2013.848256] [Medline: 24423089]

8. Blackwell CW, Dziegielewski SF. Risk for a price: sexual activity solicitations in online male sex worker profiles. J Soc Serv Res 2013 Mar;39(2):159-170. [doi: 10.1080/01488376.2012.744617]

9. Minichiello V, Scott J, Callander D. A new public health context to understand male sex work. BMC Public Health 2015;15:282 [FREE Full text] [doi: 10.1186/s12889-015-1498-7] [Medline: 25879716]

10. Nguyen M, Venne T, Rodrigues I, Jacques J. Why and according to what consultation profiles do female sex workers consult health care professionals? A study conducted in Laval, Québec. Health Care Women Int 2008 Feb;29(2):165-182. [doi: 10.1080/07399330701738226] [Medline: 18350422]

11. World Health Organization, UNFPA, UNAIDS, NSWP, World Bank, UNDP. Implementing comprehensiveHIV/STI programmes with sex workers: practical approaches from collaborative interventions. Geneva, Switzerland: World Health Organization; 2013.

12. Uy J, Parsons J, Bimbi D, Koken J, Halkitis P. Gay and bisexual male escorts who advertise on the internet: understanding reasons for and effects of involvement in commercial sex. Int J Mens Health 2004 Jan 1;3(1):11-26. [doi: 10.3149/jmh.0301.11]

13. Manning E, Bungay V. 'Business before pleasure': the golden rule of sex work, payment schedules and gendered experiences of violence. Cult Health Sex 2017 Mar;19(3):338-351. [doi: 10.1080/13691058.2016.1219767] [Medline: 27600513]

14. Hong Y, Li X, Fang X, Lin X, Zhang C. Internet use among female sex workers in China: implications for HIV/STI prevention. AIDS Behav 2011 Feb;15(2):273-282. [doi: 10.1007/s10461-010-9846-1] [Medline: 21082341]

15. Xiao Z, Li X, Lin D, Tam CC. Mass media and HIV/AID prevention among female sex workers in Beijing, China. J Health Commun 2015;20(9):1095-1106. [doi: 10.1080/10810730.2015.1018575] [Medline: 25950448]

16. The SPACES Team. Open.library.ubc. 2016. Recommendations from the off-street sex industry in Vancouver URL: https:/ lopen.library.ubc.ca/cIRcle/collections/facultyresearchandpublications/52383/items/1.0340040 [accessed 2017-01-01] [WebCite Cache ID 605AnJgUG]

17. Cunningham S, Kendall TD. Risk behaviours among internet-facilitated sex workers: evidence from two new datasets. Sex Transm Infect 2010 Dec;86(Suppl 3):iii100-iii105. [doi: 10.1136/sti.2010.044875] [Medline: 20852309]

18. McLean A. 'You can do it from your sofa': the increasing popularity of the internet as a working site among male sex workers in Melbourne. J Sociol 2015 Dec 08;51(4):887-902. [doi: 10.1177/1440783313480416] 
19. Agresti BT. search.proquest. Washington: The George Washington University, ProQuest Dissertations Publishing; 2009. E-prostitution: A Content Analysis of Internet Escort Websites: Master's Thesis URL: http://search.proquest.com/docview/ 304882040 [accessed 2017-03-24] [WebCite Cache ID 6pDUPuPCc]

20. Bungay V, Oliffe J, Atchison C. Addressing underrepresentation in sex work research: reflections on designing a purposeful sampling strategy. Qual Health Res 2016 Jun;26(7):966-978. [doi: 10.1177/1049732315613042] [Medline: 26589337]

21. Koken J, Bimbi D, Parsons J. Malefemale escorts: a comparative analysis. In: Sex for sale. 2nd ed. New York, NY: Routledge; 2010:205-232.

22. Lee-Gonyea JA, Castle T, Gonyea NE. Laid to order: male escorts advertising on the Internet. Deviant Behavior 2009 Apr 03;30(4):321-348. [doi: 10.1080/01639620802168858]

23. Pruitt MV. Online boys: male-for-male Internet escorts. Socio Focus 2005 Aug;38(3):189-203. [doi: 10.1080/00380237.2005.10571265]

24. Logan TD. Personal characteristics, sexual behaviors, and male sex work: a quantitative approach. Am Sociol Rev 2010 Oct 08;75(5):679-704. [doi: 10.1177/0003122410379581]

25. Mimiaga MJ, Reisner SL, Tinsley JP, Mayer KH, Safren SA. Street workers and internet escorts: contextual and psychosocial factors surrounding HIV risk behavior among men who engage in sex work with other men. J Urban Health 2009 Jan;86(1):54-66 [FREE Full text] [doi: 10.1007/s11524-008-9316-5] [Medline: 18780186]

26. T. Parsons, David Bimbi, Perry N. H J. Sexual compulsivity among gay/bisexual male escorts who advertise on the internet. Sexual Addict Compulsivity 2001 Apr;8(2):101-112. [doi: 10.1080/10720160127562]

27. Castle T, Lee J. Ordering sex in cyberspace: a content analysis of escort websites. Int J Cult Stud 2008 Mar 01;11(1):107-121. [doi: $10.1177 / 1367877907086395]$

28. Langanke H, Ross MW. Web-based forums for clients of female sex workers: development of a German internet approach to HIV/STD-related sexual safety. Int J STD AIDS 2009 Jan;20(1):4-8. [doi: 10.1258/ijsa.2008.008202] [Medline: 19103884]

29. Vanwesenbeeck I. Prostitution push and pull: male and female perspectives. J Sex Res 2013 Jan;50(1):11-16. [doi: 10.1080/00224499.2012.696285] [Medline: 23030049]

30. Johnson JL, Repta R. Sex and gender: beyond the binaries. In: Designing and conducting gender, sex and health research. Thousand Oaks, CA: SAGE Publishing; 2012:17-36.

31. Polit D, Hungler B. Nursing research: principles and methods. 4th edition. Philadelphia: Lippincott; 1991.

32. Krippendorff K. Content Analysis: An Introduction to Its Methodology. 2nd edition. Thousand Oaks, Calif: Sage; 2004.

33. Neuendorf KA. Content analysis: a methodological primer for gender research. Sex Roles 2010 Nov 20;64(3-4):276-289. [doi: $10.1007 / \mathrm{s} 11199-010-9893-0]$

34. Parsons JT, Koken JA, Bimbi DS. The use of the Internet by gay and bisexual male escorts: sex workers as sex educators. AIDS Care 2004 Nov;16(8):1021-1035. [doi: 10.1080/09540120412331292405] [Medline: 15511734]

35. Knapp M, Daly J. The SAGE Handbook of Interpersonal Communication. Thousand Oaks, California: Sage Publications, Inc; 2011.

36. City of Vancouver. 2016. License By-law No 4450 URL: http://former.vancouver.ca/bylaws/4450c.pdf [WebCite Cache ID 610j9CgfE]

37. Milrod C, Monto MA. The hobbyist and the girlfriend experience: behaviors and preferences of male customers of internet sexual service providers. Deviant Behavior 2012 Nov;33(10):792-810. [doi: 10.1080/01639625.2012.707502]

38. Weiss M. Techniques of Pleasure: BSDM and the Circuit of Sexuality. Durham, NC: Duke University Press; 2012.

39. Frederick BJ, Perrone D. "Party N Play" on the Internet: subcultural formation, craigslist, and escaping from stigma. Deviant Behavior 2014 Jul 29;35(11):859-884. [doi: 10.1080/01639625.2014.897116]

40. Van Den Boom W, Stolte IG, Witlox R, Sandfort T, Prins M, Davidovich U. Undetectable viral load and the decision to engage in unprotected anal intercourse among HIV-positive MSM. AIDS Behav 2013 Jul;17(6):2136-2142. [doi: 10.1007/s 10461-013-0453-9] [Medline: 23525838]

41. Kolar K, Atchison C, Bungay V. Sexual safety practices of massage parlor-based sex workers and their clients. AIDS Care 2014;26(9):1100-1104. [doi: 10.1080/09540121.2014.894611] [Medline: 24617632]

42. Smith MD, Seal DW. Sexual behavior, mental health, substance use, and HIV risk among agency-based male escorts in a small U.S. city. Int J Sex Health 2008 Mar 1;19(4):27-39 [FREE Full text] [doi: 10.1300/J514v19n04 04] [Medline: 19779600]

43. Bungay V, Halpin M, Halpin PF, Johnston C, Patrick DM. Violence in the massage parlor industry: experiences of Canadian-born and immigrant women. Health Care Women Int 2012;33(3):262-284. [doi: 10.1080/07399332.2011.603868] [Medline: 22325026]

44. Grov C, Rodríguez-Díaz CE, Ditmore MH, Restar A, Parsons JT. What kinds of workshops do Internet-based male escorts want? Implications for prevention and health promotion. Sex Res Soc Policy 2014 Mar 7;11(2):176-185. [doi: 10.1007/s13178-014-0151-z]

45. Benoit C, Shumka L. Understandingsexwork. 2015. Sex work in Canada URL: http://www.understandingsexwork.com/ sites/default/files/uploads/2015\%2005\%2007\%20Benoit\%20\&\%20Shumka\%20Sex\%20Work\%20in\%20Canada 2. pdf [WebCite Cache ID 612cmutlC] 
46. Donovan B, Harcourt C, Egger S, Fairley CK. Improving the health of sex workers in NSW: maintaining success. N S W Public Health Bull 2010;21(3-4):74-77 [FREE Full text] [doi: 10.1071/NB10013] [Medline: 20513305]

47. El-Hayek C, van GC, Bowring A, Feigin A, Stoové M. Burnet.edu. 2011. Review of clinical and health promotion services for sex workers in Western Australia: prepared for the Western Australian Department of Health URL: http://www. burnet.edu.au/system/asset/file/1125/2011 WA review of sex worker project FINAL.pdf[WebCite Cache ID 610jDn2WR]

48. Bimbi DS, Parsons JT. Barebacking among internet based male sex workers. J Gay Lesb Ment Health 2005 Oct 21;9(3-4):85-105. [doi: 10.1300/J236v09n03_06]

49. Bungay V, Kolar K, Thindal S, Remple VP, Johnston CL, Ogilvie G. Community-based HIV and STI prevention in women working in indoor sex markets. Health Promot Pract 2013 Mar;14(2):247-255. [doi: 10.1177/1524839912447189] [Medline: 22885289]

50. Holmes K, Sparling P, Stamm W, Piot P, Wasserheit J, Corey L, et al. Sexually Transmitted Diseases. 4th edition. New York, NY: McGraw Hill; 2008:0071417486.

51. Public Health Agency of Canada. Catie.ca. Report on sexually transmitted infections in Canada 2014 URL: http://www. catie.ca/sites/default/files/64-02-14-1200-STI-Report-2011 EN-FINAL.pdf [accessed 2016-10-05] [WebCite Cache ID 612cKNuLz]

52. Minichiello V, Mariño R, Browne J. Knowledge, risk perceptions and condom usage in male sex workers from three Australian cities. AIDS Care 2001 Jun;13(3):387-402. [doi: 10.1080/09540120120044035] [Medline: 11397340]

53. Handlovsky I, Bungay V, Kolar K. Condom use as situated in a risk context: women's experiences in the massage parlour industry in Vancouver, Canada. Cult Health Sex 2012 Oct;14(9):1007-1020. [doi: 10.1080/13691058.2012.712720] [Medline: $\underline{22900640]}$

54. Bernstein E. Sex Work for the Middle Classes. Sexualities 2007 Oct 01;10(4):473-488. [doi: 10.1177/1363460707080984]

55. Walby K. Touching Encounters: Sex, Work, and Male-for-Male Internet Escorting. Chicago, IL: University of Chicago Press; 2012.

56. Stall R, Herrick A, Guadamuz T, Friedman M. Updating HIV prevention with gay men: current challenges and opportunities to advance health among gay men. In: HIV prevention : a comprehensive approach. Cambridge: Elsevier; 2009:267-280.

57. Bennett GG, Glasgow RE. The delivery of public health interventions via the Internet: actualizing their potential. Annu Rev Public Health 2009;30:273-292. [doi: 10.1146/annurev.publhealth.031308.100235] [Medline: 19296777]

58. Bowen R, Bungay V. Taint: an examination of the lived experiences of stigma and its lingering effects for eight sex industry experts. Cult Health Sex 2016;18(2):186-199. [doi: 10.1080/13691058.2015.1072875] [Medline: 26671209]

59. Parsons JT, Koken JA, Bimbi DS. Looking beyond HIV: eliciting individual and community needs of male internet escorts. J Homosex 2007;53(1-2):219-240. [doi: 10.1300/J082v53n01_10] [Medline: 18019076]

60. Bowen RR. Squaring up: experiences of transition from off-street sex work to square work and duality--concurrent involvement in both--in Vancouver, BC. Can Rev Sociol 2015 Nov;52(4):429-449. [doi: 10.1111/cars.12085] [Medline: 26577882]
Abbreviations
BBBJ: bareback blowjob
BFE: boyfriend experience
CIM: cum in mouth
DATO: dining at the O/analingus
DATY: dining at the Y/cunnilingus
GFE: girlfriend experience
PNP: party and play
STI: sexually transmitted infection
WHO: World Health Organization

Edited by G Eysenbach; submitted 05.10.16; peer-reviewed by V Minichiello, Y Hong; comments to author 09.01.17; revised version
received 14.02.17; accepted 04.03.17; published 13.04.17
Please cite as:
Kille J, Bungay V, Oliffe J, Atchison C
A Content Analysis of Health and Safety Communications Among Internet-Based Sex Work Advertisements: Important Information
for Public Health
J Med Internet Res 2017;19(4):e111
URL: $\underline{\text { http://www.jmir.org/2017/4/e111/ }}$
doi: $\underline{10.2196 / j m i r .6746}$
PMID: 28408364


(CJulie Kille, Vicky Bungay, John Oliffe, Chris Atchison. Originally published in the Journal of Medical Internet Research (http://www.jmir.org), 13.04.2017. This is an open-access article distributed under the terms of the Creative Commons Attribution License (http://creativecommons.org/licenses/by/2.0/), which permits unrestricted use, distribution, and reproduction in any medium, provided the original work, first published in the Journal of Medical Internet Research, is properly cited. The complete bibliographic information, a link to the original publication on http://www.jmir.org/, as well as this copyright and license information must be included. 